\title{
The Impact of Demographic Factors on Satisfaction of Users for various Digital Payment Methods
}

\author{
Sunayna Khurana, Baljinder Kaur, Jaswinder Singh
}

\begin{abstract}
There has been significant progress in the usage of digital payment methods as alternative payment options instead of using cash. Although a majority of researches are still focusing on factors of adoption of digital payment methods, the present work moved on to the next level by examining users' present level of satisfaction. Further, this work augmented by investigating the impact of demographic factors (gender, age, education, occupation, marital status and income) on users' satisfaction with use of various digital payment methods in Amritsar, Punjab, India. A structured questionnaire was used to collect the data from 163 users of various digital payment methods. The data were analyzed using statistical techniques. The results show a significant effect of age, gender, education, occupation, marital status and income of respondents on users' satisfaction. The results of the present work revealed valuable insight into users' satisfaction with six prevailing digital payment methods vis-à-vis demographic factors.
\end{abstract}

Index Terms: Digital Payment Methods, Demographic Factors, Satisfaction, Age, Gender, Education and Occupation.

\section{INTRODUCTION}

In the past few years, the Government of India has taken many initiatives towards realizing the dream of transforming India into a digitally empowered society and knowledge economy. The significant steps comprise financial inclusion, developing a sound online infrastructure and innovative awareness programs, etc. The research studies on digital payment methods are primarily focused on adoption and acceptance factors [1]. However, the RBI payment indicator systems represent an increase in the volume of various digital payment methods as shown in Table I. The data shown in Table 1 provides a strong motive to explore another dimension of digital payment methods i.e. to determine the level of satisfaction for offering improved and enhanced services. The literature search also revealed that there is a not as much of work done in the impact of demographic factors vis-à-vis users' satisfaction with the various emerging digital payment methods. This work is an attempt to fill the research gap by investigating the impact of demographic factors on users' satisfaction with the use of digital payment methods.

\begin{tabular}{|c|c|c|c|c|c|c|c|c|}
\hline \multicolumn{9}{|c|}{$\begin{array}{c}\text { Table I: Electronic Payment Systems - } \\
\text { Representative Data } \\
\text { (Updated as on February 20, 2018) }\end{array}$} \\
\hline \multicolumn{9}{|c|}{ Volume in million } \\
\hline \multirow{2}{*}{ Year } & $\begin{array}{l}\text { RT } \\
\text { GS }\end{array}$ & $\begin{array}{l}\text { NE } \\
\text { FT }\end{array}$ & $\begin{array}{l}\text { IM } \\
\text { PS }\end{array}$ & $\begin{array}{c}\text { UP } \\
\text { I }\end{array}$ & $\begin{array}{l}\text { US } \\
\text { SD }\end{array}$ & $\begin{array}{c}\text { DC \& } \\
\text { CC }\end{array}$ & PPI & MB \\
\hline & \multicolumn{8}{|c|}{ Volume } \\
\hline $\begin{array}{l}\text { Nov- } \\
16\end{array}$ & 7.9 & $\begin{array}{c}123 \\
.0\end{array}$ & $\begin{array}{c}36 . \\
2 \\
\end{array}$ & 0.3 & 7.0 & 205.5 & $\begin{array}{c}59 . \\
0\end{array}$ & 72.3 \\
\hline $\begin{array}{l}\text { Dec- } \\
17\end{array}$ & $\begin{array}{c}10 . \\
9\end{array}$ & $\begin{array}{c}169 \\
.0\end{array}$ & $\begin{array}{c}98 . \\
0\end{array}$ & $\begin{array}{c}14 \\
5.5 \\
\end{array}$ & $\begin{array}{l}17 \\
9.9\end{array}$ & 263.9 & $\begin{array}{c}99 . \\
1\end{array}$ & 113.3 \\
\hline $\begin{array}{l}\text { Jan-1 } \\
8 \\
\end{array}$ & $\begin{array}{c}11 . \\
2\end{array}$ & $\begin{array}{c}170 \\
.2 \\
\end{array}$ & $\begin{array}{c}99 . \\
6 \\
\end{array}$ & $\begin{array}{l}15 \\
1.7 \\
\end{array}$ & $\begin{array}{l}17 \\
2.8 \\
\end{array}$ & 271.1 & $\begin{array}{c}11 \\
3.6 \\
\end{array}$ & 106.3 \\
\hline \multicolumn{9}{|c|}{$\begin{array}{l}\text { RTGS - Real time gross settlement, } \\
\text { NEFT - National electronic funds transfer, } \\
\text { IMPS - Immediate payment service, } \\
\text { UPI - Unified Payments Interface, } \\
\text { USSD - Unstructured Supplementary Service Data, } \\
\text { DC \& CC-Debit Card \& Credit Card, } \\
\text { PPI - Prepaid payment instrument and MB-Mobile Banking }\end{array}$} \\
\hline
\end{tabular}

\section{DIGITAL PAYMENT METHODS IN INDIA: AN OVERVIEW}

The Payment and Settlement Act, 2007 has defined Digital Payments as any "electronic funds transfer" means any transfer of funds which is initiated by a person by way of instruction, authorization or order to a bank to debit or credit an account maintained with that bank through electronic means and includes point of sale transfers; automated teller machine transactions, direct deposits or withdrawal of funds, transfers initiated by telephone, internet and, card payment.

As "Faceless, Paperless, Cashless" is one of the key areas of Digital India Programme under which a few methods of digital payments are selected on the basis of their applicability in the urban area as described in below Table II:
Revised Manuscript Received on June 15, 2019.

Sunayna Khurana, CBSA, CGC, Landran, Punjab, India

Baljinder Kaur, Research Scholar, IK Gujral Punjab

Technical University, Jallandhar,India

Jaswinder Singh, Dept of M E.Chitkara University, Rajpura, Punjab, India 


\begin{tabular}{|c|c|}
\hline \multicolumn{2}{|c|}{ Table II: Digital Payment Methods } \\
\hline 1.Banking Cards & $\begin{array}{l}\text { Includes credit, debit and prepaid } \\
\text { cards. }\end{array}$ \\
\hline $\begin{array}{l}\text { 2.Unstructured } \\
\text { Supplementary } \\
\text { Service Data } \\
\text { (USSD) }\end{array}$ & $\begin{array}{l}\text { *99\# service launched to take the } \\
\text { banking services to every common } \\
\text { man across the country. It does not } \\
\text { require a mobile internet data facility } \\
\text { and works on basic feature mobile } \\
\text { phone }\end{array}$ \\
\hline $\begin{array}{l}\text { 3.Unified Payments } \\
\text { Interface (UPI) }\end{array}$ & $\begin{array}{l}\text { It is a system that powers multiple } \\
\text { bank accounts into a single mobile } \\
\text { application of any participating bank. } \\
\text { Each bank provides its own UPI App } \\
\text { for Android, Windows and iOS } \\
\text { mobile platform. }\end{array}$ \\
\hline 4.Internet Banking & $\begin{array}{l}\text { Also known as online banking, } \\
\text { e-banking or virtual banking, is an } \\
\text { electronic payment system that } \\
\text { enables customers of a bank or other } \\
\text { financial institution to conduct a } \\
\text { range of financial transactions } \\
\text { through the financial institution's } \\
\text { website. }\end{array}$ \\
\hline 5.Mobile Banking & $\begin{array}{l}\text { Mobile banking is a service provided } \\
\text { by a bank or other financial } \\
\text { institution that allows its customers to } \\
\text { conduct different types of financial } \\
\text { transactions remotely using a mobile } \\
\text { device such as a mobile phone or } \\
\text { Tablet. It uses the software, usually } \\
\text { called an app, provided by the banks } \\
\text { or financial institution for the } \\
\text { purpose. }\end{array}$ \\
\hline 6.Mobile Wallet & $\begin{array}{l}\text { A mobile wallet is a way to carry } \\
\text { cash in digital format. Instead of } \\
\text { using your debit/credit cards to make } \\
\text { purchases, you can pay with your } \\
\text { smartphone, Tablet, or smart watch. } \\
\text { Most banks have their e-wallets and } \\
\text { some private companies. e.g. Paytm, } \\
\text { Freecharge, and Mobikwik, etc. }\end{array}$ \\
\hline
\end{tabular}

Source: http://cashlessindia.gov.in/digital_payment_methods.html

\section{REVIEW OF LITERATURE}

During literature search, it had been observed that the many past kinds of research were profoundly based on various models such as TAM, TAM2, and UTAUT to analyses factors affecting adoption and satisfaction of digital payment methods. Although most of the researches prepared demographics profile of respondents, further exploration of different dimensions on digital payment methods has not yet attracted the researchers. The review of the literature included nationally and internationally reputed journals spanned from 2003 to 2018. The review was focused on the demographic factors vis-à-vis satisfaction with emerging digital payment methods. The research done by Chang (2003) focused on the aspects of social structure concerning education and technology in Korea. The results proposed that the adoption of internet banking was primarily impacted by demographics and the degree of exposure to internet banking, and the features of the banks. Hogarth et al (2008) conducted a survey primarily based on examination of the consumer payment behavior. Using cluster analysis different consumers groups (technophile and technophobe) were made based on their usage pattern of varied e-payments and socio-economic, demographic, and attitudinal characteristics. It was found out younger, highly qualified, high-income level, were more likely to adopt digital payment choices than others. Kumbhar (2014) highlighted the key factors of alternative banking services provided by public and private sector that affects customer satisfaction in Satara City, Maharashtra State. The results established that there was a significant relationship between age, education and profession with customer satisfaction except for gender and income. Amin et al (2014) examined Technology Acceptance of Model (TAM) factor perceived usefulness (PU) and perceived ease of use (PEOU) along with an additional factor trust on mobile websites user's satisfaction in Malaysia. The results of structural equation modelling (SEM) indicated a significant relationship of customer satisfaction with correctly aligned PU, PEOU and trust. Ling et al (2015) identified five factors namely service quality, web design and content, security and privacy, convenience and speed of internet banking which impact customer satisfaction. The findings specified that web design and content, convenience and speed were the determining factors of customer satisfaction towards Internet banking. Singh et al (2016) added a new variable hedonism along with variables of a model in the integrated UTAUT. The results depicted a significant relationship between consumers' perception, preference, usage and satisfaction and security, trust, hedonism are few of the most influencing variables accompanied by demographic variables such as gender an age also impact consumer satisfaction and usage rate. Worku et al (2016) research specifically based on the influence of demographic factors on customer satisfaction of electronic banking in Gondar City, Ethiopia. The authors also contemplated additional factors such as branch visits, the level of customer understanding about e-banking. The survey result indicated that there was a significant relationship between demographic factors such as age, gender, education, occupation and marital status with customer satisfaction. Yaokumah et al (2017) examined the impact of demographic variables (age, gender, and the level of education) with reference to customers' preferences towards e-payment services Accra, capital of Ghana. The results suggested that there was not significant differences between the genders of the customers using e-payment services. On the other side, the examination revealed interesting pieces of evidence that male customers with higher ICT skills and a higher level of education considered e-payment less safe. Siddiqui \& Khan (2017) their work laid down the importance of analyzing the demographic factors on convenience, e-satisfaction and merchandising, perceived value and financial transactions in E-retailing. Singh and Rana (2017) focused their work on investigating customer 
perception towards digital payments

The findings revealed that only one demographic factor i.e. education affected the adoption of the digital payment in Delhi NCR rest other factors such as gender, age, profession and income were found to be not significant. The authors claimed that a customer who had studied matriculation and tech-savvy would more likely to prefer to use the digital payment mode.

\section{THE OBJECTIVE OF THE RESEARCH}

The key objective of the research is to examine the impact of demographic factors such as gender, age, education, occupation, marital status and income of users on users' satisfaction with the various digital payment methods.

\section{RESEARCH METHODOLOGY}

This research is delimited to reconnoiter the users' satisfaction with the use of various digital payment methods in Amritsar, Punjab, India. For conducting the present research, six prevalent digital payment methods namely debit and credit cards, USSD, UPI, Internet banking, mobile banking and mobile wallets. Both primary and secondary data were used for the research work. A sample of 163 digital payment methods users in Amritsar city. The primary data were collected in the month of October 2018-November 2018 using judgmental sampling technique. And the secondary data were obtained from journals, books, magazines, e-journals and research papers. A structured questionnaire was used to collect the data. For testing the normality of data Kolmogorov Smirnov and Shapiro-Wilk test was conducted using IBM SPSS 20. The Mann-Whitney and Kruskal Wallis test statistics were used to test the research hypothesis.

H0: There is no significant difference in users' satisfaction relating to the demographic factors of respondent users' digital payment methods.

For hypothesis testing, the null hypothesis was divided into the following sub-hypothesis:

H0a: There is no significant difference in the user's satisfaction relating to the gender of the respondent of digital payment methods.

H0b: There is no significant difference in the users' satisfaction relating to the age of respondent of digital payment methods.

H0c: There is no significant difference in the users' satisfaction relating to the education of respondent of digital payment methods.

H0d: There is no significant difference among the users' satisfaction relating to the occupation of the respondent of digital payment methods.

H0e: There is no significant difference among the users' satisfaction relating to the marital status of the respondent of digital payment methods.

H0f: There is no significant difference in the users' satisfaction relating to income of respondent of digital payment methods.

\section{DATA ANALYSIS AND RESULT}

A. Analysis of Demographic Profile of the respondents

The demographic profile of 163 users' of various digital payment methods of Amritsar. The demographic factors such as gender, age, education, occupation marital status, and income are exhibited Table III. The analysis for the demographic profile of respondents' exhibit out of 163 respondents, $56.4 \%$ are males and $43.6 \%$ females. In terms of age, a majority of respondents with $35.6 \%$ of 163 falls under the age-group of 36 to 50 followed by 26-35, 18-25 and above 50 years. Education status results show that $39.9 \%$ of the respondents were post-graduate followed by graduate, high school and others. There were no respondents who were illiterate or less than primary education level. Occupation results of the respondents exhibited that service class account $49.7 \%$ were the majority users followed by business class, students and others. A majority of respondents $77.9 \%$ are married followed by $22.1 \%$ who are not married.

\begin{tabular}{|c|c|c|c|}
\hline \multicolumn{4}{|c|}{$\begin{array}{c}\text { Table III: Demographic Profile of respondents of users' } \\
\text { of digital payment methods }\end{array}$} \\
\hline $\begin{array}{l}\text { Demograp } \\
\text { hic Factors }\end{array}$ & Groups & $\begin{array}{c}\text { Freque } \\
\text { ncy }\end{array}$ & Percentage \\
\hline \multirow{2}{*}{ Gender } & Male & 92 & $56.4 \%$ \\
\hline & Female & 71 & $43.6 \%$ \\
\hline \multirow{4}{*}{ Age } & $18-25$ & 33 & $20.2 \%$ \\
\hline & $26-35$ & 50 & $30.7 \%$ \\
\hline & $36-50$ & 58 & $35.6 \%$ \\
\hline & $>50$ & 22 & $13.5 \%$ \\
\hline \multirow{4}{*}{ Education } & High Class & 25 & $15.3 \%$ \\
\hline & Graduate & 63 & $38.7 \%$ \\
\hline & Post Graduate & 65 & $39.9 \%$ \\
\hline & Other & 10 & $6.1 \%$ \\
\hline \multirow{4}{*}{ Occupation } & Student & 25 & $15.3 \%$ \\
\hline & Service Class & 81 & $49.7 \%$ \\
\hline & Business Class & 35 & $21.5 \%$ \\
\hline & Housewife & 22 & $13.5 \%$ \\
\hline \multirow{2}{*}{$\begin{array}{l}\text { Marital } \\
\text { Status }\end{array}$} & Single & 36 & $22.1 \%$ \\
\hline & Married & 127 & $77.9 \%$ \\
\hline \multirow{4}{*}{$\begin{array}{l}\text { Annual } \\
\text { Income }\end{array}$} & Up to $5,00,000$ & 31 & $19.0 \%$ \\
\hline & $\begin{array}{l}5,00,000-10,0 \\
0000\end{array}$ & 82 & $50.3 \%$ \\
\hline & $>10,00000$ & 50 & $30.7 \%$ \\
\hline & Total & 163 & $100.0 \%$ \\
\hline
\end{tabular}

The test of the normal distribution of data is a pre-requisite to select most of the statistical tests for data analysis. Kolmogorov Smirnov and Shapiro-Wilk test are applied using IBM SPSS 20 to test the normalcy of the data. This test checks the variable's distribution against a perfect model of normality and indicates that the distributions are different. Table IV indicating the significance value of this test is 0.000 thus that the data is not 
normally distributed. As observed from Table IV the K-S test results for the demographic data sets show that the data set diverges from normality.

\begin{tabular}{|l|c|c|c|c|c|c|}
\hline \multicolumn{7}{|c|}{ Table IV: Tests of Normality } \\
\hline \multirow{2}{*}{$\begin{array}{c}\text { Demograp } \\
\text { hics }\end{array}$} & \multicolumn{2}{|c|}{ Kolmogorov-Smirnov } & \multicolumn{3}{c|}{ Shapiro-Wilk } \\
\cline { 2 - 7 } Factors & $\begin{array}{c}\text { Statisti } \\
\text { c }\end{array}$ & df & Sig. & $\begin{array}{c}\text { Statisti } \\
\text { c }\end{array}$ & df & Sig. \\
\hline Gender & .374 & 163 & .000 & .630 & 163 & .000 \\
\hline Age-Group & .216 & 163 & .000 & .877 & 163 & .000 \\
\hline Education & .241 & 163 & .000 & .860 & 163 & .000 \\
\hline Occupation & .294 & 163 & .000 & .850 & 163 & .000 \\
\hline $\begin{array}{l}\text { Marital } \\
\text { Status }\end{array}$ & .481 & 163 & .000 & .511 & 163 & .000 \\
\hline $\begin{array}{l}\text { Annual } \\
\text { Income }\end{array}$ & .260 & 163 & .000 & .802 & 163 & .000 \\
\hline
\end{tabular}

The data is not normally distributed thus the non-parametric tests will be used to test the hypothesis [8]. These tests are also called distribution-free tests and do not require any normality assumption for their use. These tests are more suitable for analyzing the nominal and ordinal scale data. The data collected for the present investigation is nominal and ordinal in measurement. For analyzing the data, Mann-Whitney tests will be used to test the hypothesis HOb (gender) and H0e (marital status). Further Kruskal-Wallis tests will be deployed for testing the rest of the hypothesis HOa, HOc, HOd and HOf i.e. age, education, occupation and income.

Table V: Mean Rank score Users' satisfaction with digital payment methods and gender

\begin{tabular}{|c|c|c|c|c|}
\hline $\begin{array}{l}\text { Digital } \\
\text { Payment } \\
\text { Methods }\end{array}$ & Gender & $\mathbf{N}$ & Mean Rank & Sum of Ranks \\
\hline \multirow{3}{*}{ DC } & Male & 92 & 78.37 & 7210.00 \\
\hline & Female & 71 & 86.70 & 6156.00 \\
\hline & Total & 163 & & \\
\hline \multirow{3}{*}{$\mathrm{CC}$} & Male & 85 & 83.51 & 7098.00 \\
\hline & Female & 65 & 65.03 & 4227.00 \\
\hline & Total & 150 & & \\
\hline \multirow{3}{*}{ MB } & Male & 88 & 76.34 & 6718.00 \\
\hline & Female & 71 & 84.54 & 6002.00 \\
\hline & Total & 159 & & \\
\hline \multirow{3}{*}{ IB } & Male & 90 & 76.21 & 6858.50 \\
\hline & Female & 71 & 87.08 & 6182.50 \\
\hline & Total & 161 & & \\
\hline \multirow{3}{*}{ MW } & Male & 68 & 53.82 & 3660.00 \\
\hline & Female & 49 & 66.18 & 3243.00 \\
\hline & Total & 117 & & \\
\hline \multirow{3}{*}{ UPI } & Male & 88 & 74.68 & 6572.00 \\
\hline & Female & 66 & 81.26 & 5363.00 \\
\hline & Total & 154 & & \\
\hline
\end{tabular}

To test the above-mentioned hypothesis, the Mann-Whitney test was used. It was observed from the Tables V \& VI that there is a significant difference in users' satisfaction relating to males and females as $\mathrm{p}<0.05$ in all 6 digital payment methods. The results support the finding of [13]. Hence the hypothesis was not confirmed. Mean rank suggests that females are more satisfied with the use of debit cards, mobile banking, internet banking, mobile wallets and UPI whereas males are more satisfied with credit cards.

\begin{tabular}{|l|r|r|c|r|c|r|}
\hline \multicolumn{7}{|c|}{$\begin{array}{l}\text { Table VI: Mann-Whitney Test Statistic } \\
\text { (Grouping variable-Gender) }\end{array}$} \\
\hline & DC & \multicolumn{1}{|c|}{ CC } & \multicolumn{1}{c|}{ MB } & \multicolumn{1}{c|}{ IB } & MW & \multicolumn{1}{c|}{ UPI } \\
\hline Mann-Whi & 2932 & 2082 & 2802.0 & 2763 & 1314.0 & 2656.0 \\
tney U & .0 & .0 & & .50 & & \\
\hline Wilcoxon & 7210 & 4227 & 6718.0 & 6858 & 3660.0 & 6572.0 \\
W & .0 & .0 & 00 & .50 & 00 & 00 \\
\hline Z & -2.30 & -3.03 & -1.861 & -2.3 & -2.575 & -1.462 \\
& 3 & 4 & & 34 & & \\
\hline p-value & $\mathbf{. 0 2 1}$ & $\mathbf{. 0 0 2}$ & $\mathbf{. 0 6 3}$ & $\mathbf{. 0 2 0}$ & $\mathbf{. 0 1 0}$ & $\mathbf{. 1 4 4}$ \\
\hline
\end{tabular}

H0b: There is no significant difference in the users' satisfaction with respect to the age of the respondent of digital payment methods.

\begin{tabular}{|c|c|c|c|}
\hline \multicolumn{4}{|c|}{$\begin{array}{l}\text { Table VII: Mean Rank score Users' satisfaction with digital payment } \\
\text { methods and Age }\end{array}$} \\
\hline DPM & Age-Group & $\mathbf{N}$ & Mean Rank \\
\hline \multirow{5}{*}{ DC } & $18-25$ & 33 & 69.24 \\
\hline & $26-35$ & 50 & 82.48 \\
\hline & $36-50$ & 58 & 87.59 \\
\hline & $>50$ & 22 & 85.30 \\
\hline & Total & 163 & \\
\hline \multirow{5}{*}{$\mathrm{CC}$} & $18-25$ & 22 & 67.89 \\
\hline & $26-35$ & 48 & 70.60 \\
\hline & $36-50$ & 58 & 75.71 \\
\hline & $>50$ & 22 & 93.25 \\
\hline & Total & 150 & \\
\hline \multirow{5}{*}{ MB } & $18-25$ & 29 & 52.55 \\
\hline & $26-35$ & 50 & 82.91 \\
\hline & $36-50$ & 58 & 87.04 \\
\hline & $>50$ & 22 & 91.00 \\
\hline & Total & 159 & \\
\hline \multirow{5}{*}{ IB } & $18-25$ & 31 & 54.02 \\
\hline & $26-35$ & 50 & 83.81 \\
\hline & $36-50$ & 58 & 89.57 \\
\hline & $>50$ & 22 & 90.05 \\
\hline & Total & 161 & \\
\hline \multirow{5}{*}{ MW } & $18-25$ & 33 & 52.21 \\
\hline & $26-35$ & 42 & 59.96 \\
\hline & $36-50$ & 25 & 65.46 \\
\hline & $>50$ & 17 & 60.29 \\
\hline & Total & 117 & \\
\hline \multirow{5}{*}{ UPI } & $18-25$ & 29 & 49.26 \\
\hline & $26-35$ & 49 & 77.87 \\
\hline & $36-50$ & 54 & 87.65 \\
\hline & $>50$ & 22 & 89.00 \\
\hline & Total & 154 & \\
\hline
\end{tabular}

\begin{tabular}{|l|c|c|c|c|c|c|}
\hline \multicolumn{7}{|c|}{$\begin{array}{l}\text { Table VIII: Kruskal Wallis Test Statistic } \\
\text { (Grouping variable-Age) }\end{array}$} \\
\hline & DC & CC & MB & IB & MW & UPI \\
\hline $\begin{array}{l}\text { Chi-Sq } \\
\text { uare }\end{array}$ & 14.17 & 6.85 & 36.52 & 33.71 & 4.01 & 41.44 \\
\hline df & 3 & 3 & 3 & 3 & 3 & 3 \\
\hline p-value & $\mathbf{. 0 0 3}$ & $\mathbf{. 0 7 7}$ & $\mathbf{. 0 0 0}$ & $\mathbf{. 0 0 0}$ & $\mathbf{. 2 6 0}$ & $\mathbf{. 0 0 0}$ \\
\hline
\end{tabular}

To test the above hypothesis, Kruskal Wallis Test was used. Table VII \& VIII demonstrate that there is a significant difference in users' satisfaction with the relationship with various age-group as $\mathrm{p}<0.05$ in all 6 digital payment methods. Hence, the null hypothesis is rejected. The analysis of mean ranks displays that the satisfaction is higher of age-group 36-50 respondents with $\mathrm{DC}, \mathrm{CC}, \mathrm{MB}, \mathrm{IB}$ and $\mathrm{MW}$ except for the mean rank of age-group 50 and above for UPI. H0c: There is no significant difference in the users' satisfaction with respect to the education of the respondent of digital payment methods. 


\begin{tabular}{|c|c|c|c|}
\hline \multicolumn{4}{|c|}{$\begin{array}{l}\text { Table IX: Mean Rank score Users' satisfaction with } \\
\text { digital payment methods and Education }\end{array}$} \\
\hline $\begin{array}{l}\text { Digital } \\
\text { Payment } \\
\text { Methods }\end{array}$ & Education & $\mathbf{N}$ & Mean Rank \\
\hline \multirow{5}{*}{ DC } & High Class & 25 & 79.22 \\
\hline & Graduate & 63 & 77.36 \\
\hline & Post Graduate & 65 & 86.49 \\
\hline & Other & 10 & 89.00 \\
\hline & Total & 163 & \\
\hline \multirow{5}{*}{$\mathrm{CC}$} & High Class & 20 & 65.70 \\
\hline & Graduate & 57 & 60.65 \\
\hline & Post Graduate & 63 & 88.53 \\
\hline & Other & 10 & 97.65 \\
\hline & Total & 150 & \\
\hline \multirow{5}{*}{ MB } & High Class & 23 & 63.43 \\
\hline & Graduate & 61 & 77.74 \\
\hline & Post Graduate & 65 & 86.29 \\
\hline & Other & 10 & 91.00 \\
\hline & Total & 159 & \\
\hline \multirow{5}{*}{ IB } & High Class & 24 & 63.50 \\
\hline & Graduate & 62 & 77.56 \\
\hline & Post Graduate & 65 & 88.82 \\
\hline & Other & 10 & 93.50 \\
\hline & Total & 161 & \\
\hline \multirow{5}{*}{ MW } & High Class & 23 & 62.48 \\
\hline & Graduate & 37 & 46.00 \\
\hline & Post Graduate & 47 & 68.25 \\
\hline & Other & 10 & 65.56 \\
\hline & Total & 117 & \\
\hline \multirow{5}{*}{ UPI } & High Class & 25 & 58.88 \\
\hline & Graduate & 60 & 72.03 \\
\hline & Post Graduate & 59 & 90.00 \\
\hline & Other & 10 & 88.00 \\
\hline & Total & 154 & \\
\hline
\end{tabular}

\begin{tabular}{|l|c|c|c|c|c|c|}
\hline \multicolumn{7}{|c|}{$\begin{array}{c}\text { Table X: Kruskal Wallis Test Statistic } \\
\text { (Grouping variable-Education) }\end{array}$} \\
\hline & DC & $\mathbf{C C}$ & MB & IB & MW & UPI \\
\hline $\begin{array}{l}\text { Chi-S } \\
\text { quare }\end{array}$ & 6.39 & $\begin{array}{c}22.0 \\
3\end{array}$ & $\begin{array}{c}13.6 \\
7\end{array}$ & $\begin{array}{c}15.8 \\
3\end{array}$ & 14.34 & 25.68 \\
\hline df & 3 & 3 & 3 & 3 & 3 & 3 \\
\hline $\begin{array}{l}\text { p-valu } \\
\text { e }\end{array}$ & $\mathbf{. 0 9 4}$ & $\mathbf{. 0 0 0}$ & $\mathbf{. 0 0 3}$ & $\mathbf{. 0 0 1}$ & $\mathbf{. 0 0 2}$ & $\mathbf{. 0 0 0}$ \\
\hline
\end{tabular}

To test the above hypothesis, Kruskal Wallis test was conducted. Tables IX \& X demonstrate that education has a significant difference of users' satisfaction as $\mathrm{p}<0.05$ in all 6 digital payment higher the level of education leads to more acceptability of technology and understanding of features of various digital payment methods. The results support the findings of [7].H0d: There is no significant difference among the users' satisfaction with respect to the occupation of the respondent of digital payment methods.

Table XI: Mean Rank score Users' satisfaction with digital payment methods and Marital Status

\begin{tabular}{|l|l|r|r|r|}
\hline $\begin{array}{l}\text { Digital } \\
\text { Payments } \\
\text { Methods }\end{array}$ & $\begin{array}{l}\text { Marital } \\
\text { Status }\end{array}$ & N & \multicolumn{1}{|c|}{$\begin{array}{l}\text { Mean } \\
\text { Rank }\end{array}$} & \multicolumn{1}{c|}{$\begin{array}{l}\text { Sum of } \\
\text { Ranks }\end{array}$} \\
\hline \multirow{3}{*}{ DC } & Single & 36 & 68.63 & 2470.50 \\
\cline { 2 - 5 } & Married & 127 & $\mathbf{8 5 . 7 9}$ & 10895.50 \\
\cline { 2 - 5 } & Total & 163 & & \\
\hline
\end{tabular}

\begin{tabular}{|l|l|r|r|r|}
\hline \multirow{4}{*}{ CC } & Single & 25 & 69.96 & 1749.00 \\
\cline { 2 - 5 } & Married & 125 & $\mathbf{7 6 . 6 1}$ & 9576.00 \\
\cline { 2 - 5 } & Total & 150 & & \\
\hline \multirow{4}{*}{ MB } & Single & 32 & 56.16 & 1797.00 \\
\cline { 2 - 5 } & Married & 127 & $\mathbf{8 6 . 0 1}$ & 10923.00 \\
\cline { 2 - 5 } & Total & 159 & & \\
\hline \multirow{4}{*}{ MW } & Single & 34 & 55.26 & 1879.00 \\
\cline { 2 - 5 } & Married & 127 & $\mathbf{8 7 . 8 9}$ & 11162.00 \\
\cline { 2 - 5 } & Total & 161 & & \\
\hline \multirow{3}{*}{ UPI } & Single & 35 & 53.43 & 1870.00 \\
\cline { 2 - 5 } & Married & 82 & $\mathbf{6 1 . 3 8}$ & 5033.00 \\
\cline { 2 - 5 } & Total & 117 & & \\
\cline { 2 - 5 } & Single & 32 & 52.98 & 1695.50 \\
\cline { 2 - 5 } & Married & 122 & $\mathbf{8 3 . 9 3}$ & 10239.50 \\
\cline { 2 - 5 } & Total & 154 & & \\
\hline
\end{tabular}

\begin{tabular}{|c|c|c|c|c|c|c|}
\hline \multicolumn{7}{|c|}{$\begin{array}{l}\text { Table XII: Mann-Whitney Test Statistic } \\
\text { (Grouping variable-Marital Status) }\end{array}$} \\
\hline & DC & $\mathrm{CC}$ & MB & IB & MW & UPI \\
\hline $\begin{array}{l}\text { Mann- } \\
\text { Whitne } \\
\text { y U }\end{array}$ & $\begin{array}{r}1804 \\
.500\end{array}$ & $\begin{array}{r}1424.0 \\
00\end{array}$ & $\begin{array}{r}1269.0 \\
00\end{array}$ & $\begin{array}{r}1284.0 \\
00\end{array}$ & $\begin{array}{r}1240.0 \\
00\end{array}$ & $\begin{array}{r}1167.5 \\
00\end{array}$ \\
\hline $\begin{array}{l}\text { Wilcox } \\
\text { on W }\end{array}$ & $\begin{array}{r}2470 \\
.500 \\
\end{array}$ & $\begin{array}{r}1749.0 \\
00 \\
\end{array}$ & $\begin{array}{r}1797.0 \\
00 \\
\end{array}$ & $\begin{array}{r}1879.0 \\
00 \\
\end{array}$ & $\begin{array}{r}1870.0 \\
00 \\
\end{array}$ & $\begin{array}{r}1695.5 \\
00 \\
\end{array}$ \\
\hline Z & -3.97 & -.821 & -5.469 & -5.76 & -1.537 & -5.642 \\
\hline $\mathrm{p}$-value & .000 & .412 & .000 & .000 & .124 & .000 \\
\hline
\end{tabular}

The Mann-Whitney test statistics confirm that there is a significant difference in users' satisfaction with DPM with respect to marital status as shown in Table XII. Hence the null hypothesis is rejected. Married respondents are having higher mean ranks in all six categorizes of digital payment methods followed by unmarried respondents.

HOf: There is no significant difference in the users' satisfaction with respect to income of respondent of digital payment methods.

\begin{tabular}{|c|c|c|c|}
\hline \multicolumn{4}{|c|}{$\begin{array}{l}\text { Table XIII: Mean Rank score Users' satisfaction with } \\
\text { digital payment methods and Income }\end{array}$} \\
\hline $\begin{array}{l}\text { Digital } \\
\text { Payment } \\
\text { Methods }\end{array}$ & Annual Income & $\mathbf{N}$ & Mean Rank \\
\hline \multirow{4}{*}{ DC } & Up to 500000 & 31 & 78.48 \\
\hline & $500000-1000000$ & 82 & 83.04 \\
\hline & $>1000000$ & 50 & 82.48 \\
\hline & Total & 163 & \\
\hline \multirow{4}{*}{$\mathrm{CC}$} & Up to 500000 & 21 & 67.24 \\
\hline & $500000-1000000$ & 79 & 69.45 \\
\hline & $>1000000$ & 50 & 88.53 \\
\hline & Total & 150 & \\
\hline \multirow{4}{*}{ MB } & Up to 500000 & 29 & 74.41 \\
\hline & $500000-1000000$ & 80 & 79.25 \\
\hline & $>1000000$ & 50 & 84.44 \\
\hline & Total & 159 & \\
\hline \multirow{4}{*}{ IB } & Up to 500000 & 31 & 68.21 \\
\hline & $500000-1000000$ & 80 & 83.25 \\
\hline & $>1000000$ & 50 & 85.33 \\
\hline & Total & 161 & \\
\hline MW & Up to 500000 & 26 & 66.33 \\
\hline
\end{tabular}




\begin{tabular}{|l|l|c|c|}
\multirow{5}{*}{} & $500000-1000000$ & 51 & 59.44 \\
\cline { 2 - 4 } & $>1000000$ & 40 & 53.68 \\
\cline { 2 - 4 } & Total & 117 & \\
\hline \multirow{4}{*}{ UPI } & Up to 500000 & 30 & 66.33 \\
\cline { 2 - 4 } & $500000-1000000$ & 76 & $\mathbf{8 0 . 8 6}$ \\
\cline { 2 - 4 } & $>1000000$ & 48 & 79.16 \\
\cline { 2 - 4 } & Total & 154 & \\
\hline
\end{tabular}

The Kruskal Wallis test statistics confirm that there is a significant difference in users' satisfaction with DPM with respect to income as shown in Table 16. Hence the null hypothesis is rejected. The analysis of mean ranks emphasis that respondents with annual income above 10,0000 have higher satisfaction level with credit cards, mobile banking and internet banking, Respondents with annual income between 5,00,000-10,0000 have higher satisfaction with debit cards and UPI followed by mobile wallets with annual income less than 5,00,000.

\begin{tabular}{|l|c|c|c|c|c|c|}
\hline \multicolumn{7}{|c|}{$\begin{array}{l}\text { Table XIV: Kruskal Wallis Test Statistic } \\
\text { (Grouping variable-Income) }\end{array}$} \\
\hline & DC & CC & MB & IB & MW & UPI \\
\hline $\begin{array}{l}\text { Chi-Squa } \\
\text { re }\end{array}$ & .920 & 9.383 & 2.542 & 7.449 & 3.870 & $\begin{array}{c}6.20 \\
4\end{array}$ \\
\hline df & 2 & 2 & 2 & 2 & 2 & 2 \\
\hline p-value & .631 & .009 & .281 & .024 & .144 & .045 \\
\hline
\end{tabular}

\section{CONCLUSION}

The results of testing all the sub-hypothesis supported the findings of [12] as demographic factors such as gender, age, education, occupation, marital status and income impact users' satisfaction towards digital payment methods. It is recommended that the banks and others financial institutions should consider the above mentioned six demographic factors of each user while providing services, as each user has individual needs and preferences according to his/her demographic characterizes. The banks as the major institution who deliver digital payment services have a critical role in building the initial thrust, development and support of digital payments infrastructure and systems. The users have varied of digital payment options and many of these are interoperable and work through bank accounts [10].

\section{REFERENCES}

1. Izogo, E.E., Nnaemeka, O.C., Ama, O., Onuoha, Ezema, K.S., "Impact of Demographic Variables on Consumers' Adoption of E-banking in Nigeria: An Empirical Investigation", European Journal of Business and Management, vol. 4(17), 2012. ISSN 2222-1905 (Paper) ISSN 2222-2839 (Online).

2. G. Worku G, A. Tilahun, MA Tafa,"The Impact of Electronic Banking on Customers' Satisfaction in Ethiopian Banking Industry (The Case of Customers of Dashen and Wogagen Banks in Gondar City)", 4 J Bus Fin Aff, BSFA an open access journal, vol. 5(2), 2013. ISSN: 2167-0234

3. Goh Mei Linga, Yeo Sook Ferna, Lim Kah Boona, Tan Seng Huata, "Understanding Customer Satisfaction of Internet Banking: A Case Study In Malacca", Fifth International Conference on Marketing and Retailing (5TH INCOMaR), vol. 37, 2016, pp. 80-85.

4. http://cashlessindia.gov.in/digital_payment_methods.html

5. Jeanne M. Hogarth, Jane Kolodinsky, Tatiana Gabor, "Consumer payment choices: paper, plastic, or electrons?” Int. J. Electronic Banking, vol. 1(1), 2008.

6. Muslim Amin, Sajad Rezaei, Maryam Abolghasemi, "User satisfaction with mobile websites: the impact of perceived usefulness (PU), perceived ease of use (PEOU) and trust", Nankai Business Review International, vol. 5(3), 2014, pp.258-274.

https://doi.org/10.1108/NBRI-01-2014-0005
7. Shamsher Singh and Ravish Rana, "Study of Consumer Perception of Digital Payment Mode", Journal of Internet Banking and Commerc, vol. 22(3), 2017. (http://www.icommercecentral.com)

8. Shraddha Parab and Supriya Bhalerao, "Choosing statistical test" ,Int J Ayurveda Res., vol. 1(3), 2010, pp. 187-191. doi: 10.4103/0974-7788.72494

9. Siddiqui U.A. \& Khan M. S., "An Exploratory Study on Effect of Demographic Factors on Consumer Satisfaction and its Determinants in E-Retailing”, Management Studies and Economic Systems (MSES), vol. 3(3), 2017, pp. 159-171.

10. T. Y Chang, "Dynamics of Banking Technology Adoption: An Application to Internet Banking", University of Warwick workshops, the European Association for Research in Industrial Economics Conference, 2003

11. The Report of High Level Committee on Deepening of Digital Payment, 2019.

https://rbidocs.rbi.org.in/rdocs/PublicationReport/Pdfs/CDDP03062019 634B0EEF3F7144C3B65360B280E420AC.PDF

12. Vijay M. Kumbhar, "Alternative Banking Channels and Customers' Satisfaction: An Empirical Study of Public and Private Sector Banks", International Journal of Business and Management Tomorrow, vol. 1(1), 2011.

13. Winfred Yaokumah, Peace Kumah, and Eric Saviour Aryee Okai "Demographic Influences on E-Payment Services", International Journal of E-Business Research, vol. 13(1), 2017.

\section{AUTHORS PROFILE}

Dr Sunayna Khurana has done $\mathrm{PhD}$ in Service Marketing, MBA in Marketing, UGC NET qualified, currently working as Professor and HOD, MBA at Chandigarh Business School of Administration. She deals in Service Marketing, Consumer Behavior, Advertising and Sales management, Retail Management, Marketing Research. She is recipient of National Award of Best Professor in Marketing in 11th DNA Innovative Education Leadership Awards in 2019. She has more than 12 years' experience in academics and 3 years' experience in corporate sector. She is also guiding $8 \mathrm{PhD}$ scholars under IKGPTU out of which one student also awarded the $\mathrm{PhD}$ degree. She has written 40 research papers for various referred International \& National Journals

Ms Baljinder Kaur is an Assistant Professor at Chandigarh Business School of Administration, CGC Landran Punjab. She is pursuing PhD from IK Gujral Punjab Technical University, Jalandhar. Her core area is Marketing, consumer behavior and Marketing research. She has 19 years' experience; 8 years in corporate and 11 years in teaching. She has published several papers in reputed national and international journal and conference proceedings

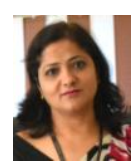

Dr Jaswinder Singh is working as Associate Professor in Mechanical Engineering department of Chitkara University, Punjab, India. He has received BE Degree from BBSEC Engineering College, Fathegarh sahib and ME Degree from PEC University of Technology, Chandigarh, India in the year 2002 and 2010 , respectively. He has received his $\mathrm{PhD}$ in 2014 from PEC University of Technology, Chandigarh. He has supervised several M.Tech. Thesis. His research interests include $\mathrm{CAD} / \mathrm{CAM}$ and product design and Ergonomics.
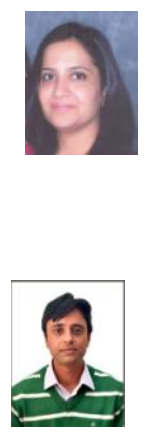